\title{
Militarism in Civil Organization: Study of Front Pembela Islam (FPI) and Forum Komunikasi Anak Betawi (Forkabi)
}

\author{
Lusi Andriyani ${ }^{1}$, Ali Noerzaman ${ }^{2}$ \\ \{lusi.andriyani@umj.ac.id ${ }^{1}$, zamanalinoer@gmail.com² \\ Universitas Muhammadiyah Jakarta, Indonesia ${ }^{1,2}$
}

\begin{abstract}
Purpose: investigate the models of militarism in FPI and Forkabi During the New Order era in Indonesia. Method/Design: This study is based on interviews with FPI and forkabi. The qualitative descriptive method is used to analyze and describe the militarization in FPI and Forkabi with used indicator military attitudes, mentality and ideals are civil society organization. Findings: FPI is a community organization that has experienced militarism. This is shown in the hierarchical organizational structure, with ranks and military training, repression and violence, and a bipolar view of life. The militarization in FPI is caused by the background of his birth which is largely supported by top figures from the military and police. Forkabi is a community organization that has experienced militarization only at the boundary of the preparation of the organizational structure that is tiered to the level of the neighborhood. Forkabi's programs and activities focus more on civil security such as guarding vacant lots and parking. The activity was carried out for the solidarity of fellow Betawi people. Especially for members who are still lacking economically, as well as socio-cultural activities. The militarization of Forkabi was motivated by the presence of Forkabi's founder who came from the TNI. Originality: in the field of civil society studies.
\end{abstract}

Keywords: Militarism, FPI, Forkabi, Civil Organization.

\section{Introduction}

During the New Order era, the political structure was dominated by the military or the Armed Forces of the Republic of Indonesia (ABRI), which was used by the Suharto government to perpetuate its power through the dual functions of ABRI [1][2]. In the dual functions of the Armed Forces in addition to maintaining the integrity and security of the Republic of Indonesia, ABRI also functions to maintain social and political stability. Of course, it is important to note here that ABRI is not the sole support of President Suharto's power.

Within the framework of carrying out the function of social and political stability, ABRI has representatives in the DPR and the MPR appointed. The number of ABRI members in the DPR is 100 out of DPR members, while at the DPRD I and DPRD II the proportion adjusts to the total membership. Members of the DPR, known as the ABRI faction, have the same duties and authority as members of the DPR representing political parties who are elected directly through general elections. Political parties have to work hard to seduce voters to get that many 
representatives. So, it is not surprising that positions in the leadership of the DPR are always filled by members from the army or those who are close to the army.

While in government, many members of ABRI are employed in civilian positions such as regents, governors' positions in ministries and other high state institutions. With an indirect election system and carried out by members of DPRD I for the election of governors and members of DPRD II for regents, candidates from the military can be ascertained as parties to be elected. Because they will be supported by the ABRI faction whose members are large. While for strategic ministry positions, such as the Minister of Defense/Security and the Minister of the Interior, it is always filled by representatives from ABRI. The vice president is also filled by those with an army background. Only Vice President Adam Malik and Vice President Habibie were civilians. In this way, their praxis can control the bureaucratic machinery.

However, the political structure collapsed due to the 1998 wave of reform that was driven by students, non-governmental organizations, and other non-parliamentary forces. ABRI got a bad image because it was seen as a support of President Suharto's power for more than 30 years; not only that, ABRI was also associated with various human rights violations, such as in the Tanjung priuk riots in 1984, mass shootings in Santa Cruz, Dili, East Timor, on 12 November 1991, the attack on the Indonesian Democratic Party's Office on 27 July 1996, and later the May 1998 riots. In short, ABRI's image deteriorated in the public eye.

So the years after 1998 were marked by ABRI's efforts to reform itself. President Abdurahman Wahid who came to power to replace President Habibie pushed for ABRI reform by separating the army from the police. The army institution changed its name to the Indonesian National Army which is administratively integrated with the ministry of defense and is responsible for the defense and wholeness of the Republic of Indonesia, while the police are in a separate institution directly under the President with the responsibility of maintaining national security. Army representation in parliament was also removed and since the 2004 elections, all members of the DPR were the result of the election. Civil positions such as governors and regents are filled by civil candidates.

Withdrawal of the army from the political stage does not mean civilian dominance in politics. Conversely, many army officers or retirees are actively involved in politics. In the 2004 elections, for example, of the four pairs of presidential and vice president candidates who competed, three of them were from a military background. Several political parties were also led and established by former soldiers, such as the Democratic Party, the Indonesian Justice and Unity Party (PKPI), and the Gerindra Party. They are also easily found to be involved as general chairmen of several social and sports organizations, for example, Farmers and Fishermen Association, Indonesian National Sports Committee and Badminton Association of Indonesia, Indonesian Pencak Silat Association, Indonesian Amateur Boxing Association, and the Sports Federation Karate-Do Indonesia (FORKI).

If the army has formally withdrawn from social and political involvement, this does not mean that military attitudes, mentality, and ideals are independent of civilians. On the contrary, many military-style civilian organizations were born after the reforms in 1998. For example, first, the Islamic Defenders Front (FPI), which was founded on August 17, 1998, in Ciputat, South Tangerang, by habib and ulama and was chaired by Habib Rizieq Sihab. This organization wants to uphold Islamic sharia through amar ma'ruf nahi munkar. To realize this, FPI raided shopping centers that are considered to sell prohibited goods such as alcoholic drinks, gambling centers, and prostitution. They also demanded the dissolution of the Ahmadiyya organization, which was seen as deviating from Islam. So, it is not surprising if FPI is labeled as an organization that often uses violence. They are known for their neat 
organization and military-like command system. Second, the Betawi Children Communication Forum (FORKABI), which began to emerge in 2001. This organization was founded with the reason to help maintain the order of Jakarta which is currently engulfed by anarchism due to political instability in the era of President Abdurrahman Wahid and specially to defend the interests of the Betawi. As the name suggests, this organization was founded by Betawi figures or at least those close to this ethnic group such as H. Husain Sani, Lt. Gen. (Ret) H.M. Sanif, H. Abdul Khair (deceased), H. Syah Manaf, H. Salman Mochtar, H. Nukman Muhasyim, Komarudin Darip, Police Colonel H. Asmuni Mochtar, H. Irwan Syafi'ie, H. Sofyan, Syarif Hidayatullah, S. Ip, and Mohammad Ihsan, SH. Just like the Islamic Defenders Front, on the pretext of maintaining order and security, FORKABI is also often involved in violence and clashes with other organizations. Their organization is neatly organized like a command system in the military.

The presence of civilian but military-style organizations in the era of democracy after the New Order regime is interesting to study. Because it shows the still strong influence of the military in the minds of the Indonesian people and at the same time an anomaly. The era of democracy is generally characterized by enthusiasm and civic values in the life of the state and society. In this study, have 3 problems that will be answered: (1) relating to the description of militaristic organizations in FPI and Forkabi, (2) the organization's views of military ideals and mentality. (3) civil-military relations represented by FPI and Forkabi.

\section{Literatur Review}

There are several books, that discuss the Islamic Defenders Front. First, Khamami Zada [3], Radical Islam: The upheaval of Hardline Islamic mass organizations in Indonesia. Khamami Zada's book highlights a lot of theological and ideological aspects of hardline Islamic movements, one of which is the Islamic Defenders Front. According to Hamami, the Islamic Defenders Front developed and implemented Islamic teachings based on literal understanding. They emphasize the spirit of purification of Islam and distance themselves from values that are considered un-Islamic. They are what are considered to be Western values (Westernism) which currently afflict and undermine the morality of Muslims throughout the world [4], [5]. Following accordance with the education received by its founders, such as Habib Rizieq, FPI wants to uphold Islamic values as it is in Muslim countries such as Saudi Arabia. Violence is needed because it is a form of jihad. Secondly, the Radical Salafi Movement in Indonesia written by Jamhari and Jahroni [6]. The two writers who became lecturers at Jakarta State Islamic University described Islamic organizations that were considered radical from a historical and sociological point of view. Therefore, the revealed side is the behavior of the Islamic Defenders Front which often causes violence in the capital when they are about to commit amar ma'ruf nahi munkar.

From the books repeated above, none of them have discussed military-style organizational systems in organizations such as the Islamic Defenders Front with Forkabi, their views are related to military ideals and mentality in civilian organizations, especially when linked to patterns of civil relations-military. Besides, the books above see radical organizations such as FPI as Islamic organizations, and less focus on ethnic Betawi backgrounds, which are very thick in the structure and ideology of Forkabi, and FPI in several respects. 


\subsection{Military and Civilization Militaries in a Democratic System}

A democratic system is a necessity for a modern state. Huntington [7], a realist who focuses on issues of civilization, democracy and civil-military relations, defines democracy, as a form of government, based on the source of authority for the government, the goals served by the government, and the procedures for forming a government. While Joseph Schumpeter put forward what democracy is an institutional procedure for obtaining political decisions in which individuals gain the power to make decisions through competitive struggles to again popular votes.

Democracy is a way that ensures the principle of equality exists and runs in state organizations. While the State as the largest social organization in society has a function; protect the public from threats or harassment and guarantee community rights. Therefore, the state as a large organization is given the authority by its people to carry out these obligations. The aim is to try to consolidate common goals and interests among the general public. In a democratic system where the state acts as a protector of society from threats and disturbances, the military's position in a country should function so that threats and disturbances

We can learn more about the military's function in a democratic state from the principles offered by Major General (Retired) Genschel [8]. The principles referred to are as follows:

1) The military is part of the executive power of governance. Thus, the military is an element of the separation of powers in a democratic political system, which is characterized by the separation of legislative, executive and judicial powers;

2) The military is under political leadership which has been democratically endorsed, with the post of defense minister held by civilians;

3) The military follows the political guidelines outlined;

4) The military obeys and is subject to the law;

5) The military is limited by the tasks stipulated by the constitution; regularly maintain external security of the country (from attacks or threats from outside) and maintain national defense. In certain cases, with certain situations and boundaries clearly outlined. (The military can be involved) in efforts to maintain the internal security of the country under the command of the police;

6) The military is neutral in politics;

7) The military is not justified in having access to financial support outside the state budget;

8) The military is controlled by parliament, political leadership, judicial power, and civil society in general;

9) The military has clear responsibilities based on the professional expertise it possesses and hence, has its dignity and dignity.

To support the principles stated above, the preconditions required:

1) The constitutional framework; establish social values (human dignity and human rights) and government based on the law, determine the separation of powers (legislative, executive, judicial power), define the role and duties of the military;

2) A functioning Parliament; (elected through) free elections, (is) multi-party, (and has) necessary sub-structures (such as budget committees, defense committees, parliamentary ombudsmen);

3) Civil government; with a clear (political) chain of command. President, Minister of Defense and by placing the Chief of Defense under the Minister of Defense - in 
Germany the chain of command starts from the President to the Prime Minister, and so on;

4) Independent judicial power; without special courts outside its responsibility (such as a military court);

5) Military organizations; structured, educated, and guided in such a way that it does not interfere or endanger civil society, but while maintaining high military effectiveness;

6) Mature civil society; which is united under the basic provisions of the constitution and takes a pluralistic but tolerant attitude in social life, which in turn requires;

7) Educated public; who are willing to participate in political life and social life, can balance individual freedom.

8) and independence with a commitment to the common good (including defense), as well as free and diverse media;

9) Competent military and political elite;

10) Position holders in public offices (both civilian and military) who have confidence, are willing to fulfill obligations, assume responsibilities, and accept restrictions (that is; civil servants need not fear the military. Conversely, military personnel should fulfill their obligations proudly within given legal restrictions).

While some of the main things that need to be placed under political and parliamentary control are: 1) Civil and military relations-military integration into society; 2) Legal framework, social welfare, and security; 3) leadership, training and education style; 4) Combat readiness. In this study more emphasis on the context of civil militarization. The understanding of militarism/civil militarization is taken from several kinds of literature, including; First, according to the Collin Dictionary of Sociology [9]. Militarism is to make war an intrinsic value and glorification of military ideals; equitable distribution of military values and military practices in society; the tendency in some societies to find military solutions in political conflicts and the lower classes tend to accept these solutions. Second, based on the American Heritage Dictionary (2nd College edition) [10], militarism means the veneration of noble values of professional military classes; (The glorification of the ideals of a professional military class); The dominance of the army in the administration of state policy (Predominance of the military in the administration of policy of the state). A policy in which military readiness is a state priority (a policy in which military preparedness is of primary importance to the state) based on the two concepts above, can be seen several values that develop in the Military, namely:

1) The Relationship of Superiority-Inferiority;

2) Hierarchy in military organizations;

3) Bipolar given life (creating racism, sexism, homophobia and other forms of discrimination) in other word bipolar in this case ambiguous in behaving, example; do not tolerate violence but they are against violence;

4) Violence and repression, heroism and obedience. 


\section{Research Method}

This research will be directed to a descriptive form or detailed story from the informant to be able to describe the internalization of military values to mass organizations (civil society). This type of research uses a qualitative approach. Data collection techniques carried out through interviews, observation, documentation. This technique is useful for gathering information about the development of CSOs that can be seen through the activities they do in the community. To answer questions related to militarism of internal organizations in South Tangerang City. The data obtained were analyzed using qualitative methods with an explanatory descriptive model that was intended to be more effective and intense to see the active role and programs of CSOs.

\section{Problem and Discuss}

\subsection{FPI (Front Pembela Islam)}

FPI is a community organization that has a legal entity and is registered with the Directorate General of Politics and Public Administration of the Ministry of Home Affairs with Registered Certificate Number: 01-00-00/010/D.III.4/V. FPI was registered on June 20, 2014, and is valid until June 20, 2019. The highest organizational structure in the Central Leadership Council (DPP) domiciled in Jakarta, at the Provincial level is called the Regional Leadership Council (DPD), at the level called the Regional Leadership Council (DPW), the Branch Leadership Council at the District, DPRa or referred to The Branch Management Board at the sub-district level and the Command Post at the neighbor, RW/RT level.

FPI is a movement organization with institutional format and form. The FPI's organizational mechanism is not determined by default but is determined temporally and conditionally according to the needs of the movement. While the leaders of the movement have full authority to take policy and determine the direction of movement of this group. FPI also does not have rules to rotate leadership, everything is left to the elite consisting of habib and ulama. The existing organizational structure is only intended to facilitate coordination and division of tasks in carrying out the movement. In 2013 after the National Conference III the management structure changed with the appointment of Al Habib Muhammad Rizieq bin Husein Bin Syihab as High Priest of the Islamic Defenders Front for a time. This decision was taken in the Third General Meeting of the General Assembly. The position of FPI's High Priest is the highest position above the Shura Council and the Tanfidzi Council, but the duties and authority of the FPI High Priest is only a symbol of the organization and can provide insight if needed and cannot take and decide on any policy in the organization.

FPI management structure in the form of a hierarchy from top to bottom starts from:

1) FPI High Priest

2) Shura Council; The management structure of the Shura Assembly is chaired by a Chairperson and Secretary and 5 board chairs, namely:
a) Sharia Board
b) Board of Trustees
c) Advisory Board
d) God of Trustees
e) Honorary Council with each board secretary and several members on it 
3) Tanfidz Council; The FPI tanfidzi council is commanded by a general chairperson who plays an important role as the highest command and highest policymaker in FPI. Assisted by the deputy chairperson and general secretary and general treasurer. As well as 5 fields, all fields are assisted by secretaries and treasurers. that is:
a) Da'wah
b) Hisbah
c) Jihad
d) Khilafah Enforcement Division
e) Organization Furthermore, under the coordination of the organizational

\subsubsection{FPI has autonomous organizational}

1) Special Bodies consisting: (a) Front Expert Bodies (BAF). (b). Front Investigation Agency (BIF). (c) Front cadre body (BPF). (d). Anti-terror front agency (BanTF). (e). Amil zakat (BAZ).

2) Autonomous Institutions consisting of: (a). Institution of da'wah fronts. (b). Front Economic Institutions. (c). Front legal aid agencies. (d). Front Information Institutions. (e). Community Monitoring Institute.

3) Subsidiary Organizations consisting of: (a). Islamic Defenders Warriors (LPI). (b). Mujaidah Defender of Islam (MPI). (c). Islamic Student Front (FMI). (d). Front Workers Union (SPF). (e). Hilal Merah Indonesia (HILMI).

4) Department which consists of: (a). Foreign Relations. (b). Interfaith Relations. (c). Relationships among CSOs. (d). Social and Political Relations. (e). Art and Culture Relations.

5) Secretariat.

\subsubsection{Another Special Body Consisting in FPI}

1) FPI has a special body consisting:

a) Front Expert Board (BAF)

b) Front Investigation Agency (BIF)

c) Front cadre body (BPF)

d) Anti-terror front agency (BanTF)

e) Amil zakat (BAZ)

2) Autonomous Institutions consisting of:
a) Institution of da'wah fronts
b) Front Economic Institutions
c) Front legal aid agencies
d) Front Information Institutions
e) Community Monitoring Institute

3) Children's Organizations consisting:

a) Islamic Defenders Warriors (LPI)

b) Mujaidah Defender of Islam (MPI)

c) Islamic Student Front (FMI)

d) Front Workers Union (SPF)

e) Hilal Merah Indonesia (HILMI)

4) The department consists of:

a) Foreign Relations 

b) Interfaith Relations
c) Relationships among CSOs
d) Social and Political Relations
e) Art and Culture Relations

\subsubsection{Militarism in FPI}

The process militarization in FPI organization begin at the moment FPI build relationship with military. The relationship between FPI, Wiranto and the military leaders regarding the formation of a self-defense aimed at protecting the Special Session of the MPR on November 10-13, 1998. FPI in its stance on SI-MPR 1998, No. 003/DPP-FPI/XI/1998 on November 7 , 1998 , by stating the first stance, fully supporting the implementation of the 1998 SI-MPR as long as it is in line with reform demands. Second, supporting all forms of actions carried out peacefully to provide input to the SI-MPR. Third, reject and oppose all forms of anarchist actions aimed at frustrating the 1998 SI-MPR and dividing the unity and integrity of the nation. Fourth, relinquish and entrust the full security of the implementation of the 1998 SIMPR to the security forces and firmly reject the self-help security system that involves the masses, because it could lead to mass clashes. However, if the security forces are unable to resolve the situation, securing the self-service system becomes an unavoidable necessity.

Speculation of the closeness between FPI and Military officials especially the Army was very visible when FPI celebrated the 1st anniversary attended by General TNI (Ret.) Wiranto, Kostrad Commander Lieutenant General Djadja Suparman, Metrojaya Regional Police Major General Noegroho Djajoesman ABRI Kaster Lieutenant General, Susilo Bambang Yudhoyono.

As an organization rife with violence, the Islamic Defenders Front, through its autonomous organizational, army of defending Islam, conducts military-style training, even with assistance from the TNI. This has been published in the news titled "TNI and FPI held PPBN (Preliminary Training of National Defense) and planted 10,000 trees in the Lebak Regency of Banten," wrote the dpp fpi account as a caption for photos of PPBN training uploaded. The military training process illustrates that FPI has militaristic values developed in its organization.

\subsection{Forkabi (Forum Komunikasi Anak Betawi)}

Forkabi is a certain ethnic-based community organization. Forkabi was formed by the Betawi community based on the concern of the ethnic Betawi fading because of the many tribes of migrants in Jakarta. By looking at these conditions, it can be explained that Forkabi was formed because of concerns from the Betawi people because they felt that their ethnic group had no place in the development process in Jakarta. Betawi communities are rarely raised in the news or activities in Jakarta.

\subsubsection{The Forkabi Militarization Process}

Forkabi was founded by H. Husein Sani, one of the Betawi figures. The word Forkabi itself was first proposed by H. Salman Muchtar Betawi. The official Forkabi is used as a name in the organization as short for "Betawi Children's Communication Forum". Forkabi eventually emerged as a Betawi organization engaged in multiple fields involving the interests of the Betawi community as part of Jakarta's pluralism. Forkabi is a Betawi community 
organization in Jakarta that uses its Betawian identity. The aim is to advance the Betawi community in an increasingly narrow economic field. The Forkabi is located at Jalan Kramat Sentiong Raya No. 49 B Central Jakarta. Forkabi was formed not only because of the Betawi people's concern about their exclusion from the current of urbanization, but also due to the occurrence of conflict and commotion between the Betawi ethnic and Madurese who were more economically stable. As migrants in Jakarta, the Madurese occupy an economic position better than the Betawi ethnic group as a native of Jakarta.

The purpose of the formation of Forkabi is to hit all the problems of the Betawi community with deliberation to make the Betawi community better. the purpose of Forkabi is to elevate the dignity of the Betawi people so that: being an actor in his village, being proud of being a Betawi, being respected at the same time being loved by fellow nation's children, and being able to embrace people who are not native Betawi in to feel an inseparable part of the Betawi people, Betawi culture by both the Indonesian people and the international community. The description of the organization is also stated in the symbols used. Where the Forkabi logo is symbolized by a golden star is expected to be able to provide a bright light by strengthening the friendship between fellow Betawi people to create just prosperity. The development of Forkabi was not only in Jakarta, but also extended to the areas of Depok, Bogor, Banten and other areas as a place for friendship between the Betawi people.

Vision and mission Forkabi is to elevate the Betawi people's dignity and preserve and develop Betawi culture. Forkabi was founded based on Pancasila and Islamic teachings with the aim of: (1). Trying to improve the dignity of the Betawi community so that the Betawi. (2). Maintain, foster and enhance the unity and unity of the Betawi community in particular and the Indonesian people in general. (3). Developing and preserving Betawi culture that can be admired by the people of Indonesia, internationally and at the same time as a filter against the adverse effects of cultural globalization. (4). Join to maintain and fight for the safety, security, and integrity of the unitary State of the Republic of Indonesia which always gets the blessing of Allah SWT.

\subsubsection{Management and Organizational Hierarchy Forkabi}

Forkabi has an organizational structure up to the RT level. Nutmeg makes Forkabi has the power and take root in the community. Structured to the RT level, Forkabi has positioned itself as a strong ethnic-based community organization.

The Forkabi management structure consists of:
a) Chairperson
b) Deputy Chairperson
c) Secretary-General
d) Deputy Secretary-General
e) Advisory Board
f) Treasurer

The general organizational structure of Forkabi is as follows:

a) Forkabi's central leadership board (DPP)

b) Forkabi Regional Leadership Council (DPD)

c) Forkabi's Branch Leadership Board (DPC)

d) Forkabi Branch of the Branch Management Board (DPRT)

e) Forkabi Sub-branch Leadership Board

f) Management of Forkabi at the neighborhood (RT) level called Korta (Neighbor's Coordinator) 
g) Forkabi's Regional Outside Leadership Council (DPLD) with the scope of authority outside the province of DKI Jakarta

h) Forkabi's Foreign Leadership Council (DPLN), with the scope of authority abroad

\section{Conclusion}

Based on the explanation above, it can be concluded:

a) The Islamic Defenders Front is a community organization that has experienced militarism. This is shown in the hierarchical organizational structure, with ranks and military training, repression and violence, and a bipolar view of life.

b) Militarization in the Islamic Defenders Front is also caused by his birth background which is largely supported by top figures from the military and police.

c) Forkabi is a community organization that has experienced militarization only at the boundary of the preparation of the organizational structure that is tiered to the level of the neighborhood.

d) The Forkabi programs and activities are more focused on the context of civil security such as guarding vacant land and parking. The activity was carried out for the solidarity of fellow Betawi people. Especially for members who are still lacking economically, as well as socio-cultural activities.

e) The militarization of Forkabi was motivated by the presence of the founder of Forkabi who came from the TNI.

\section{References}

[1] H. Crouch, The Army and Politics in Indonesia. Jakarta: Equinox, 2007.

[2] N. Notosusanto, The Dual Function of The Indonesian Armed Forces, Especially Since 1966. Dept. of Defence \& Security, Centre for Armed Forces History, 1970.

[3] K. Zada, Islam Radikal: Pergualtan Ormas-ormas Islam Garis Keras di Indonesia. Teraju, 2002.

[4] J. L. Esposito, Dialektika Peradaban: Modernisme Politik dan Budaya diakhir Abad 20. Yogyakarta: Qalam, 1999.

[5] J. L. Esposito, Identitas Islam Pada Perubahan Sosial Politik. Jakarta: Bulan Bintang, 1986.

[6] Jamhari and J. Jahroni, Gerakan Salafi Radikal di Indonesia. PT RajaGrafindo Persada, 2004.

[7] S. P. Huntington, "Tertib Politik di Tengah Pergeseran Kepentingan Massa," Jakarta, RajaGrafindo Persada, 2003.

[8] D. Genschel, Tempat dan Peran Militer dalam Masyarakat Sipil yang Demokratis: Pengalaman Reformasi Militer Jerman. 2002.

[9] D. Jary and J. Jary, Collin Dictionary of Sociology (ed.). Collins, 2005.

[10] M. \& C. Houghton, American Heritage Dictionary (2nd College edition). 1982. 